\title{
Review
}

Pharmacology

\section{Potential Causes and Present Pharmacotherapy of Irritable Bowel Syndrome: An Overview}

\author{
Theodor Bokic ${ }^{a}$ Martin Storr ${ }^{b}$ Rudolf Schicho ${ }^{a}$ \\ ${ }^{a}$ Institute of Experimental and Clinical Pharmacology, Medical University of Graz, Graz, Austria; \\ ${ }^{\mathrm{b}}$ Center of Endoscopy, Starnberg, Germany
}

\section{Key Words}

IBS · Functional bowel disorders · Pharmacological treatment

\begin{abstract}
Background: Irritable bowel syndrome (IBS) is currently one of the most common disorders of the digestive system in the Western society. Almost 2 out of 10 people suffer from IBS with women being more affected than men. IBS is associated with abdominal pain, bloating and altered stool consistency and imposes a heavy burden for the affected patients. Summary: The pathophysiology of IBS remains elusive although potential causes have been suggested, such as a deranged brain-gut signaling, hypersensitivity of visceral sensory afferent fibers, bacterial gastroenteritis, small intestinal bacterial overgrowth (SIBO), genetic alterations and food sensitivity. Targets for the pharmacotherapy of IBS include the serotonergic and opioidergic system, and the microbial population of the gut. Alternative therapies like traditional Chinese medicine have shown some success in the combat against IBS. Key Messages: Many therapeutics for the treatment of IBS have emerged in the past; however, only a few have met up with the expectations in larger clinical trials.
\end{abstract}

Additionally, the multifactorial etiology of IBS and its variety of cardinal symptoms requires an individual set of therapeutics. This review provides a short overview of potential causes and current pharmacological therapeutics and of additional and alternative therapies for IBS.

(c) 2015 S. Karger AG, Basel

\section{Introduction}

Irritable bowel syndrome (IBS), a functional bowel disorder associated with alterations of stool habits, seriously affects social life, health-being, regular daily activities and diets of affected subjects $[1,2]$. It is one of the most frequent gastroenterological (GI) diseases in the industrialized world [1]. As a functional disorder, IBS typically lacks histopathological, biochemical or visual differences to healthy individuals. The severity of IBS strongly varies and limits the quality of life [3]. Often, a variety of symptoms occur, consisting of abdominal pain, bloating, nausea, an irregular but more frequent urge to defecate, and an altered stool consistency (sometimes switching between softer and harder stool forms) $[2,4,5]$. After a bowel movement, IBS sufferers lack the feeling of com-

\section{KARGER 125}

(c) 2015 S. Karger AG, Base

0031-7012/15/0962-0076\$39.50/0

E-Mail karger@karger.com

www.karger.com/pha
Rudolf Schicho, $\mathrm{PhD}$

Medical University of Graz

Institute of Experimental and Clinical Pharmacology

Universitätsplatz 4, AT-8010 Graz (Austria)

E-Mail rudolf.schicho@medunigraz.at 
plete emptying [4]. Among the symptoms, abdominal pain is the most frustrating and found in almost all IBS patients $[3,6,7]$. A questionnaire was administered to people diagnosed with IBS; it was found that these respondents suffered from IBS symptoms on average for 16.6 years with $57 \%$ reporting their symptoms daily occurring and $16 \%$ responded to have experienced symptoms even for as long as 21-30 years [8]. Eighty percent of respondents were taking some form of treatment at the time the questionnaire was administered [8].

For the diagnosis of IBS, the Rome III criteria for functional GI disorders were introduced after revision of Rome II criteria [9]. Rome I criteria were not so useful to capture information of all IBS patients [10]. Although Rome III criteria were introduced several years ago, authors in a recent systematic review reported that the new criteria were still poorly adopted and utilized [11]. Previously, the exclusion of any organic disease was sufficient for considering IBS; however, a diagnosis of IBS, based on the exclusion of organic pathology alone, is no longer valid according to current definitions [12]. To diagnose a functional bowel disorder like IBS, symptoms need to persist for more than 6 months - symptoms such as alternating constipation, diarrhea, abdominal pain, and bowel irregularities. 'Red flags', that is, alarm symptoms that include weight loss, anemia, nocturnal symptoms, fecal blood, disorders of malabsorption and thyroid function should be assessed and in case they are present, testing for organic causes is warranted [13]. The most common symptoms, that is, diarrhea, constipation, pain perception or an alternation between diarrhea and constipation, are used to divide IBS into subgroups. IBS is thus categorized into IBS-C (constipation-predominant), IBS-D (diarrhea-predominant), IBS-M (mixed type), and IBS-U (unsubtyped) [9].

\section{Epidemiology and Risk Factors}

IBS is a disorder that varies depending on the regional location of the population affected by this condition. It occurs in the western world in $10-20 \%$ of the population, depending on the diagnostic criteria used [14]. In North America, prevalence estimates range from 10 to $15 \%$ [15], and are $11.1 \%$ in Australia [16]. A meta-analysis of studies on IBS epidemiology estimates a global prevalence of $11.2 \%$ [17]. Compared with the Western countries, Southeast Asia and especially China have a low prevalence of IBS, which lie between 5 and 7\% [18, 19]. Apparently, India has the lowest prevalence of IBS (4.2\%) [20].

Risk factors of IBS are manifold, such as depression, war experiences with malnutrition, and various infec- tious epidemics that trigger gastroenteritis episodes [2123]. A type of bacterial gastroenteritis has been shown to be a major independent risk factor for the development of IBS [24]. Additionally, an expired infectious gastroenteritis in combination with stress is believed to potentiate IBS [21]. Anxiety associated with GI symptoms exaggerates symptoms of IBS-D [23]. In a population-based study, a significant association between IBS and sexual, emotional or verbal abuse as well as between IBS and abuse in childhood or adulthood has been found [25]. Stressful moments like exams, a birth weight of less than $1,500 \mathrm{~g}$, early traumatic events in childhood, and a strict childhood deprivation can trigger the development of IBS $[23,26]$. A family history of IBS, being a female and a hysterectomy also constitute important risk factors $[27$, $28]$. Thus, IBS of the constipation and pain subtype was more common in hysterectomy patients than in controls [29].

\section{Potential Causes of IBS}

Functional GI diseases, such as IBS, have multifactorial pathophysiologies and are not fully explored. For IBS to develop, cellular and molecular processes could occur individually or in combination. For instance, following a preceding inflammation, lymphocytes and cytokines are increased in the intestinal mucosa of patients with IBS $[30,31]$. Other likely causes include visceral hypersensitivity and abnormal intestinal motility. Some of the possible causes of IBS are discussed in the following sections.

\section{Disturbances in the Intestinal Bacterial Colonization}

The bowel of a fetus is not colonized by bacteria until the time of birth. Only after the birth process, first bacteria, and then fungi and protozoa orally reach the newborn and colonize the intestine. An individual microbial intestinal balance that stabilizes over time is thus created in every single human being [32]. During this time, variations in the composition of the bacterial strains may have been already formed and the basis for the development of IBS could have been laid [32]. Through daily food intake, we regularly select different bacterial populations in our intestinal flora, which in turn can affect physiological GI functions. This complex bacterial system makes up the so-called microbiome, which consists of about 100 trillion bacteria [32]. There is now good indication that fecal microbiota and organic acids are altered in IBS patients $[33,34]$. GI infections may induce a change in the bacterial colonization of a normal intesti- 
nal flora and as this change continues, it may contribute to the development of IBS. IBS could be therefore triggered either by an expired pathogenic infection or by bacterial products that affect the motility and secretion of the gut, or even the brain [35-37]. It is recognized that a change in the bacterial lawn of E. coli, Lactobacilli and Bifidobacteria is present in the IBS diarrhea-type [32]. Scanu et al. [38] suggested that Mycobacterium avium ssp. paratuberculosis, a pathogen that causes chronic watery diarrhea and inflammatory bowel reactions, plays a critical role in the development of IBS. In this small cohort study, infection with Mycobacterium avium ssp. paratuberculosis was detected in about $75 \%$ of IBS patients as compared to $15 \%$ of healthy people. The probability of having IBS was $17 \times$ higher in infected than in noninfected subjects [38].

\section{Small Intestinal Bacterial Overgrowth}

As indicated by the term, small intestinal bacterial overgrowth (SIBO) occurs in the upper part of the small bowel and can be caused by dysmotility, altered gastric acid secretion, blind or afferent loops, and partial obstruction [39]. Whether SIBO plays a role in IBS is not quite clear. A small clinical study of 162 IBS patients did not indicate that SIBO played an important role in IBS, although it was found that slightly increased counts of small-bowel bacteria were more common in the IBS group [40]. A review on studies using different diagnostic methods for investigating the prevalence of SIBO in IBS patients concluded that although the frequency of SIBO in IBS varied from 4 to $78 \%$, SIBO was higher in IBS patients than in controls [41]. Therefore, an association between SIBO and IBS seems likely, or in other words, there may be a high likelihood of yet not diagnosed SIBO in patients with IBS.

\section{Gut-Brain Axis}

The central nervous system (CNS) affects all the features of the GI tract, such as bowel movements, the perception of intestinal pain, and the illness behavior. A derangement along the intestinal brain-axis, for instance, by the increase of the HPA axis activity, can, therefore, cause changes in the CNS, which could lead to IBS symptoms $[42,43]$. A malfunction of the GI tract may also occur at the level of the enteric nervous system and contribute to IBS [44]. A dysregulation in brain areas may then cause altered processing in the CNS and eventually lead to an abnormal perception of visceral pain. For instance, rectosigmoid distension caused greater activation of the amygdala, rostroventral anterior cingulate cortex, and dorso- medial frontal cortical regions in IBS patients than in healthy individuals [45]. Additionally, the emotional modulation of the neural responses to visceral stimuli may be distorted in people with IBS [46]. Therefore, the daily thinking, feeling and acting may be constantly influenced by visceral pain, in a way that many activities are consistently avoided and solitude and tranquility are preferred by those with IBS [23].

\section{Diet as a Possible Cause of IBS}

Intake of certain foodstuff and irregular or improper eating habits represent additional potential triggers of IBS $[47,48]$. A survey suggested that IBS may be associated with a higher consumption of canned food, processed meat, legumes, whole cereals, confectionary, fruit compotes and herbal tea [48]. Fast food, fried foods, food irritants that can be found in cow's milk, eggs, wheat, soy, nuts, citrus fruits, fish, marine fish and chocolate, can interfere with the movements of the intestine and result in symptoms such as constipation, diarrhea and flatulence $[49,50]$. The motility of the small intestine can be reduced by a high fat diet and soluble fiber [49]. With regard to food intolerance or allergies, a recent review concluded that no convincing data existed to link these factors with IBS [51]. Rather, certain food items rich in poorly absorbed short-chain carbohydrates (FODMAPs) and insoluble fibers may trigger IBS symptoms [51].

\section{The Role of Mast Cells in the Etiology of IBS}

Mast cells can secrete mediators, such as histamine, serotonin, cytokines, arachidonic acid derivatives as well as tryptases and proteases. Through the release of these mediators, primary afferent neurons respond with increased excitability. Barbara et al. found that the infiltration of the colon with mast cells and the release of mediators in proximity to mucosal innervation likely contribute to abdominal pain perception in IBS patients [52]. In particular, serotonin has been shown to act locally at nerve endings and to contribute to the sensation of intestinal pain [53]. Mast cell infiltration may come about as a reaction to expired earlier moments of stress, which may affect the frequency and severity of the perceived pain [54]. The facts (i) that mast cells lie in close proximity to nerve endings, (ii) that their mediators released have sensorimotor function, (iii) that their activation produces IBS-like symptoms and (iv) that mast cell stabilizers, such as sodium cromoglycate, show efficacy in alleviating symptoms in IBS patients and suggest that mast cells could be causative of IBS symptoms [54]. 


\section{Pharmacotherapy of IBS}

The pharmacological therapy is the most common form of therapy for IBS and medication is based on individual symptoms. Substances mentioned here are already in use, still in clinical evaluation or have been withdrawn from the market due to serious side effects.

\section{Pharmacotherapy of IBS-C}

IBS-C is characterized by the predominance of constipation associated with abdominal pain, which is relieved by defecation. Lumpy stools occur in $\geq 25 \%$ and loose or watery stools in $<25 \%$ of bowel movements [9]. Bloating and abdominal pain are more common in IBS-C than IBS-D patients [55]. For symptomatic relief of discomfort in IBS-C, prokinetic and laxative agents (e.g. macrogol, bisacodyl and lactulose) are used. Linaclotide, a guanylate cyclase-C agonist, has various effects on digestion and effectively improves abdominal pain and bowel symptoms. It simultaneously reduces stool consistency and increases the frequency of bowel movements. The most common side effect is diarrhea, which is the reason why around 5\% of patients have discontinued treatment during phase III trials [56].

Lubiprostone activates a voltage-gated chloride ion channel that promotes the transport of chloride ions across the intestinal epithelium. It thereby enhances fluid secretion and accelerates stool frequency. It also reduces abdominal pain and is regarded as a good treatment option due to its limited side effects (diarrhea and dizziness) [57].

Tegaserod $\left(\right.$ Zelmac $\left.^{\circledR}\right)$ is a selective and partial $5-\mathrm{HT}_{4}$ receptor agonist that reduces visceral sensitivity and stimulates the secretion of chloride from epithelial cells. It has been shown to reduce discomfort and pain in IBS $[58,59]$. Although long-term safety of tegaserod was investigated in a prospective study, from which it was suggested that treatment was safe over a 12 -month period (despite serious adverse events in $4.4 \%$ of patients) [60], the drug has been withdrawn from the market in 2007 [61].

Prucalopride is also a 5- $\mathrm{HT}_{4}$ receptor agonist and is active in severe chronic constipation [62]. It has been shown to accelerate colonic transit time [63]. As a rare side effect, prucalopride may produce cardiovascular events [64]. However, the drug does not lead to prolongation of the QT-interval, which occurs frequently with $5-\mathrm{HT}_{4}$ agonists [65]. Due to insufficient data, prucalopride is currently only indicated for women with IBS [66]. Another prokinetic agent, pumosetrag, is a partial $5-\mathrm{HT}_{3}$ receptor agonist. Positive effects of the drug on IBS-C were reported by the company in a phase II proof-of-concept trial [67].

Cisapride is a $5-\mathrm{HT}_{4}$ receptor agonist and a $5-\mathrm{HT}_{3}$ receptor antagonist with prokinetic effects in the stomach, thereby accelerating gastric emptying. It was removed from the market for producing nonrhythmic cardiac output $[68,69]$. In spite of this action, cisapride is still available in Third-World countries and via Internet, although no obvious benefit for IBS has been demonstrated [70].

Velusetrag is another $5-\mathrm{HT}_{4}$ receptor agonist that also acts as a prokinetic agent. According to a placebo-controlled and dose-response study, it is efficacious and well tolerated in patients with chronic idiopathic constipation [71].

\section{Pharmacotherapy of IBS-D}

IBS-D, the diarrhea-predominant subtype of IBS, is characterized by loose (mushy) or watery stools occurring in $\geq 25 \%$ and by hard or lumpy stools in $<25 \%$ of bowel movements [9]. IBS-D patients do not report on upper GI symptoms as often as people with IBS-C do [55].

Loperamide, a $\mu$-opioid receptor agonist, decreases gastric emptying, delays intestinal transit, relaxes the segmental colonic spasm and acts against diarrhea, while stool frequency is reduced [72]. An increase in nocturnal pain after loperamide intake, however, has been observed in IBS patients [73]. Loperamide may be used in the treatment of adults with IBS-D [74].

Alosetron is a $5-\mathrm{HT}_{3}$ receptor antagonist and is effective in female IBS patients with predominant diarrhea or alternating constipation and diarrhea [75]. It is a therapeutic agent with limited use and available only for IBS-D (and that too only for women). It improves pain and discomfort but is an absolute no-go for the therapeutic use in IBS-C [74].

Crofelemer binds to the CFTR channel (cystic fibrosis transmembrane conductance regulator) and reduces chloride ion secretion in the intestinal epithelium. It provides some visceral analgesic effects and improves stool consistency in symptomatic diarrhea [76]. In a trial of IBS-D patients, crofelemer failed to improve stool consistency after a treatment of 12 weeks; however, a significant increase in the number of pain-free days was noted in female patients [77].

Clonidine is an agonist at presynaptic $\alpha_{2}$-receptors and inhibits sympathetic efferent outflow. Agonists of $\alpha_{2}$ adrenergic receptors were found to modulate colorectal sensation and motility in humans suggesting that they may be of use in the treatment of IBS [78]. However, in a 
prospective, placebo-controlled study in women with urge-predominant fecal incontinence, symptom severity and bowel symptoms (stool consistency or frequency) were unaffected by treatment with clonidine, although a slightly improved fecal continence was seen in the patients with diarrhea [79].

Solabegron is a selective $\beta_{3}$-adrenergic agonist and still in the developmental phase. It hardly affects GI transit time but seems to have an influence on pain [80]. It also decreases hyperexcitability of enteric neurons, which is the basis for its beneficial effects in IBS [81].

Octreotide is a somatostatin-2 receptor agonist and is commonly used for the treatment of growth hormoneinduced tumors. In IBS patients, octreotide increases thresholds of visceral perception without changing the muscular tone of the colon [82]. In a study of long-term treatment in 46 non-constipated IBS patients, octreotide improved stool consistency and increased first sensation threshold but had no effect on abdominal pain [83].

The benefit of antidepressant therapy, especially that of IBS-D, was recognized nearly 50 years ago [84]. Tricyclic antidepressants such as amitriptyline are applied in low doses and they are usually well tolerated [84-86]. In IBS patients, amitriptyline may also significantly reduce brain activation during rectal pain in combination with stress conditions [87].

\section{Treatment of Pain in IBS}

For the therapy of pain in IBS, neurokinin receptor antagonists, selective serotonin reuptake inhibitors (SSRIs) and glutamatergic excitation inhibitors have been used $[84,85,88]$. In case of unresponsiveness to these agents, benzodiazepines provide certain benefit (especially in IBS-D). They are believed to affect the inflammatory, neural, and psychological pathways. The use of benzodiazepines in IBS, however, is still a controversial issue [89]. Regarding sensory threshold and pain, pregabalin, a second-generation $\alpha_{2} \delta$-ligand, showed significant improvement in a trial of 26 IBS patients. Larger trials are warranted to prove the efficacy and safety of the drug before recommendation [90]. Melatonin was able to significantly attenuate abdominal and rectal pain sensitivity in IBS patients with sleep disturbances [91]. Interestingly, sleep disturbances did not improve by melatonin treatment, indicating that the benefit from melatonin was independent of sleep behavior [91].

Fluoxetine and citalopram are serotonin reuptake inhibitors (SSRIs) widely used in IBS treatment. Fluoxetine reduces abdominal pain and discomfort in IBS-C and decreases sense of bloating [88], while the benefit of citalo- pram on relieving IBS symptoms has been described as modest at the most [92].

Symptoms of abdominal pain may ease when treated with antispasmodics. A meta-review, which analyzed 22 trials in 1,778 IBS patients, revealed clear beneficial effects of antispasmodics over placebo; however, consistent evidence of efficacy were shown only for otilonium and hyoscine [93]. Another widely used smooth muscle-relaxing agent in IBS, mebeverine, is well tolerated with no significant adverse reactions, but its efficacy in IBS has not yet been firmly proved [94].

\section{Probiotics and Antibiotics}

Probiotics are live microorganisms intended to provide benefit for the consumer. They are used as nondigestible food ingredients that positively affect the host by enhancing the growth of certain strains of bacteria in the colon $[32,95]$. Probiotics are thought to interfere with inflammatory responses in the gut, enhance the barrier function or reduce visceral hypersensitivity, and favor a balanced composition of bacteria in the intestines. This may lead to an improvement of symptoms and increased psychological well-being $[96,97]$. In a clinical trial with 362 female primary care IBS patients, Bifidobacterium infantis improved global IBS symptoms by more than $20 \%$ [98]. Also, after a 4-week-treatment of IBS patients with Lactobacillus acidophilus, abdominal pain or discomfort were reduced by more than $20 \%$, as compared to placebo [99]. However, in a recent randomized, double-blind, placebo-controlled trial, in which IBS patients received a probiotic mixture of Lactobacillus paracasei ssp. paracasei F19, Lactobacillus acidophilus La5 and Bifidobacterium Bb12 over 6 months, no differences in GI symptoms were noticed between the cohorts [100]. Although health-related quality of life improved in the IBS group, it did not statistically differ from the placebo group [100].

Abdominal pain occurs when there is a reduced ability to emit gas. Antibiotics have been long used to relieve symptoms of IBS, probably because antibiotics interfere with SIBO and, therefore, reduce gas production [101]. Among them, rifaximin conferred significant relief of global IBS symptoms, such as bloating and abdominal pain, in two phase III double-blind and placebo-controlled trials with non-constipated IBS patients (TARGET 1 and TARGET 2) [102]. A small study showed that metronidazole provided benefit for IBS patients without affecting rectosigmoid motility [103]. In a double-blind, placebo-controlled trial, neomycin improved constipation in IBS-C [104]. The improvement was dependent on
Bokic/Storr/Schicho 
the production and elimination of methane, as determined by breath test [104]. A meta-analysis on the use of antibiotics confirmed their beneficial effects in IBS; however, the authors of the study noted that routine use of antibiotics in IBS is not yet recommended due to the lack of pathophysiological explanation [105].

\section{Anti-Allergic and Anti-Inflammatory \\ Pharmacotherapy}

Sodium cromoglycate is a drug from the group of mast cell stabilizers, which inhibits the release of mediators, such as histamine, serotonin and leukotrienes. According to an earlier study, it can improve persistent diarrhea by $40 \%$ [106]. Since the study was performed in a low sample size, newer data are warranted. Ketotifen is an $\mathrm{H}_{1}$-blocker, thus exerting antihistaminic effects. It has been shown to reduce the sensitivity in the gut and to improve quality of life in patients with IBS [107]. In a prospective study, mesalazine (5-aminosalicylic acid) provided benefit in IBS$\mathrm{D}$ patients with regard to days of discomfort and bowel movement satisfaction [108]. A larger randomized placebo-controlled study could not confirm whether patients with IBS-D benefit from a treatment with mesalazine [109].

\section{Possibilities of New Pharmacotherapies for IBS: \\ The Endocannabinoid System}

In traditional medicine (especially in Asia), extracts of Cannabis sativa, were used to treat inflammation and diarrhea. During the past decade, the existence of a socalled endocannabinoid system, which encompasses the cannabinoid receptors and their endogenous ligands, was described. Its possible purpose in the GI tract is to maintain homeostasis [110]. Active ingredients of Cannabis, such as $\Delta^{9}$-tetrahydrocannabinol (THC) and cannabidiol, may be candidates for pharmacological intervention in IBS. The THC-derivative dronabinol is currently in use for the treatment of people with AIDS and cancer to increase appetite [111]. Activation of cannabinoid receptors in enteric neurons attenuates the hyperexcitability in the gut [112] and slows exaggerated contractions during intestinal inflammation [113]. In a retrospective study, Crohn's disease patients reported improvement of their disease and a reduction in the required conventional pharmacotherapy after treatment with cannabis [114]. Cannabinoids may be, therefore, useful for the treatment of inflammatory processes and motility disturbances of the GI tract, a situation that also applies for IBS.

Dronabinol has been already used in trials with IBS patients. When taken orally, it is metabolized by about
$90-95 \%$, which means only $10-20 \%$ of the oral dose actually reaches the systemic circulation [115]. Dronabinol was effective in reducing fasting colonic motility in IBS patients with diarrhea or alternating [116]. In another trial, dronabinol was without effect on gut transit with only a modest delay in colonic transit in subjects with a CNR1 rs806378 single nucleotide polymorphism, indicating that the group of IBS patients that might benefit from dronabinol remains to be determined [117].

\section{Additional and Alternative Therapies}

One way of meeting the challenge of IBS treatment is the use of herbal medicine. For instance, the intake of essential oils, such as peppermint oil (Menta piperita), may reduce stool frequency and could represent an adjunctive therapy to IBS-D with little side effects [118]. Traditional Chinese Medicine (TCM) may represent an alternative form of IBS therapy. TCM applies empiric diagnostics approaches, such as the pulse and tongue diagnosis, for IBS [119]. Alternative forms of IBS treatment can achieve good therapeutic results and can, in some cases, be almost as effective as conventional therapy. According to a study by Chedid et al., herbal therapy was equivalent to rifaximin in the treatment of SIBO [120]. In a TCM study of 60 individuals suffering from IBS, symptoms improved in 43 subjects [121]. In 11 subjects, an apparent improvement was noted, whereas in 6 subjects, no improvement was observed [121]. IBS patients may also experience some benefit from acupuncture [122]. However, data are still inconclusive whether acupuncture is more effective than sham acupuncture or other therapies in alleviating IBS symptoms [123]. A cognitive behavioral therapy for IBS patients may be also helpful, for instance, a 'gut-focused hypnosis' has been reported to improve quality of life and scores for anxiety and depression in IBS [124]. Because of the involvement of intestinal dysbiosis, fecal transplantation has been discussed as a future option for the treatment of IBS [125].

\section{Conclusion}

It is broadly accepted that IBS is a multifactorial disease and influenced by numerous mechanisms. Causes of IBS are multifold, leading to a complex of symptoms that requires different pharmacological treatments as well as supportive and alternative treatment options. The past years has seen an increase in effective pharmacotherapeutics. However, treatment of symptoms associated with 
IBS using conventional pharmacotherapy may cause dissatisfaction of patients and health care professionals alike. Most likely, the multifactorial etiology of the disease and its variety of cardinal symptoms warrant a broad and individual set of therapeutics. Considering that IBS is one of the most expensive health care management-related GI diseases in some countries, the introduction of new therapeutics is urgently awaited.

\section{Acknowledgments}

Work in the lab of R.S. is supported by the Austrian Science Fund (FWF P25633).

\section{Disclosure Statement}

The authors have no conflict of interest to declare.

\section{References}

1 Chey WD, Kurlander J, Eswaran S: Irritable bowel syndrome: a clinical review. JAMA 2015;313:949-958.

2 Song SW, Park SJ, Kim SH, Kang SG: Relationship between irritable bowel syndrome, worry and stress in adolescent girls. J Korean Med Sci 2012;27:1398-1404.

3 Mearin F, Baró E, Roset M, Badía X, Zárate N, Pérez I: Clinical patterns over time in irritable bowel syndrome: symptom instability and severity variability. Am J Gastroenterol 2004;99: 113-121.

4 Viera AJ, Hoag S, Shaughnessy J: Management of irritable bowel syndrome. Am Fam Physician 2002;66:1867-1874.

5 Whorwell PJ: What is irritable bowel syndrome? Therap Adv Gastroenterol 2012;5: 379-380.

6 Heaton KW, O'Donnell LJ, Braddon FE, Mountford RA, Hughes AO, Cripps PJ: Symptoms of irritable bowel syndrome in a British urban community: consulters and nonconsulters. Gastroenterology 1992;102: 1962-1967.

7 Srinath AI, Walter C, Newara MC, Szigethy EM: Pain management in patients with inflammatory bowel disease: insights for the clinician. Therap Adv Gastroenterol 2012;5: 339-357.

8 Silk DB: Impact of irritable bowel syndrome on personal relationships and working practices. Eur J Gastroenterol Hepatol 2001;13: 1327-1332.

9 Longstreth GF, Thompson WG, Chey WD, Houghton LA, Mearin F, Spiller RC: Functional bowel disorders. Gastroenterology 2006;130:1480-1491.

10 Bommelaer G, Dorval E, Denis P, Czernichow P, Frexinos J, Pelc A, Slama A, El Hasnaoui A: Prevalence of irritable bowel syndrome in the French population according to the Rome I criteria. Gastroenterol Clin Biol 2002;26: 1118-1123.

11 Dang J, Ardila-Hani A, Amichai MM, Chua K, Pimentel M: Systematic review of diagnostic criteria for IBS demonstrates poor validity and utilization of Rome III. Neurogastroenterol Motil 2012;24:e853-e897.

12 Camilleri M: Irritable bowel syndrome: how useful is the term and the 'diagnosis'? Therap Adv Gastroenterol 2012;5:381-386.
13 Black TP, Manolakis CS, Di Palma JA: 'Red flag' evaluation yield in irritable bowel syndrome. J Gastrointestin Liver Dis 2012;21: 153-156.

14 Endo Y, Shoji T, Fukudo S: Epidemiology of irritable bowel syndrome. Ann Gastroenterol 2015;28:158-159.

15 Saito YA, Schoenfeld P, Locke GR 3rd: The epidemiology of irritable bowel syndrome in North America: a systematic review. Am J Gastroenterol 2002;97:1910-1915.

16 Ng KS, Nassar N, Hamd K, Nagarajah A, Gladman MA: Prevalence of functional bowel disorders and faecal incontinence: an Australian primary care survey. Colorectal Dis 2014, Epub ahead of print.

17 Lovell RM, Ford AC: Global prevalence of and risk factors for irritable bowel syndrome: a meta-analysis. Clin Gastroenterol Hepatol 2012;10:712-721.e4.

18 Fass R: Irritable bowel syndrome: a global view. J Gastroenterol Hepatol 2003;18:10071009.

19 Xiong LS, Chen MH, Chen HX, Xu AG, Wang WA, Hu PJ: A population-based epidemiologic study of irritable bowel syndrome in Guangdong province. Zhonghua Yi Xue Za Zhi 2004;84:278-281.

20 Gwee KA, Lu CL, Ghoshal UC: Epidemiology of irritable bowel syndrome in Asia: something old, something new, something borrowed. J Gastroenterol Hepatol 2009;24: 1601-1607.

21 Gwee KA, Leong YL, Graham C, McKendrick MW, Collins SM, Walters SJ, Underwood JE, Read NW: The role of psychological and biological factors in postinfective gut dysfunction. Gut 1999;44:400-406.

22 Mearin F: Postinfectious functional gastrointestinal disorders. J Clin Gastroenterol 2011; 45(suppl):S102-S105.

23 Surdea-Blaga T, Băban A, Dumitrascu DL: Psychosocial determinants of irritable bowel syndrome. World J Gastroenterol 2012;18: 616-626.

24 Rodríguez LA, Ruigómez A: Increased risk of irritable bowel syndrome after bacterial gastroenteritis: cohort study. BMJ 1999;318:565566.

25 Talley NJ, Fett SL, Zinsmeister AR, Melton LJ 3rd: Gastrointestinal tract symptoms and self- reported abuse: a population-based study. Gastroenterology 1994;107:1040-1049.

26 Gulewitsch MD, Enck P, Hautzinger M, Schlarb AA: Irritable bowel syndrome symptoms among German students: prevalence, characteristics, and associations to somatic complaints, sleep, quality of life, and childhood abdominal pain. Eur J Gastroenterol Hepatol 2011;23:311-316.

27 Locke GR 3rd, Zinsmeister AR, Talley NJ, Fett SL, Melton LJ 3rd: Familial association in adults with functional gastrointestinal disorders. Mayo Clin Proc 2000;75:907-912.

28 Anbardan SJ, Daryani NE, Fereshtehnejad SM, Taba Taba Vakili S, Keramati MR, Ajdarkosh H: Gender role in irritablebowel syndrome: a comparison of irritable bowel syndrome module (ROME III) between male and female patients. J Neurogastroenterol Motil 2012;18:70-77.

29 Longstreth GF, Preskill DB, Youkeles L: Irritable bowel syndrome in women having diagnostic laparoscopy or hysterectomy. Relation to gynecologic features and outcome. Dig Dis Sci 1990;35:1285-1290.

30 Liebregts T, Adam B, Bredack C, Röth A, Heinzel S, Lester S, Downie-Doyle S, Smith E, Drew P, Talley NJ, Holtmann G: Immune activation in patients with irritable bowel syndrome. Gastroenterology 2007;132:913-920.

31 Drossman DA, Camilleri M, Mayer EA, Whitehead WE: AGA technical review on irritable bowel syndrome. Gastroenterology 2002;123:2108-2131.

32 Lee BJ, Bak YT: Irritable bowel syndrome, gut microbiota and probiotics. J Neurogastroenterol Motil 2011;17:252-266.

33 Tana C, Umesaki Y, Imaoka A, Handa T, Kanazawa M, Fukudo S: Altered profiles of intestinal microbiota and organic acids may be the origin of symptoms in irritable bowel syndrome. Neurogastroenterol Motil 2010; 22:512-519.e114-e115.

34 Kassinen A, Krogius-Kurikka L, Mäkivuokko H, Rinttilä T, Paulin L, Corander J, Malinen E, Apajalahti J, Palva A: The fecal microbiota of irritable bowel syndrome patients differs significantly from that of healthy subjects. Gastroenterology 2007;133:24-33.

35 Collins SM, Surette M, Bercik P: The interplay between the intestinal microbiota and the brain. Nat Rev Microbiol 2012;10:735-742. 
36 Camilleri M: Peripheral mechanisms in irritable bowel syndrome. N Engl J Med 2012; 367:1626-1635.

37 Steck N, Mueller K, Schemann M, Haller D: Bacterial proteases in IBD and IBS. Gut 2012; 61:1610-1618.

38 Scanu AM, Bull TJ, Cannas S, Sanderson JD, Sechi LA, Dettori G, Zanetti S, HermonTaylor J: Mycobacterium avium subspecies paratuberculosis infection in cases of irritable bowel syndrome and comparison with Crohn's disease and Johne's disease: common neural and immune pathogenicities. J Clin Microbiol 2007;45:3883-3890.

39 Quigley EM, Quera R: Small intestinal bacterial overgrowth: roles of antibiotics, prebiotics, and probiotics. Gastroenterology 2006; 130(2 suppl 1):S78-S90.

40 Posserud I, Stotzer P, Björnsson ES, Abrahamsson H, Simrén M: Small intestinal bacterial overgrowth in patients with irritable bowel syndrome. Gut 2007;56:802-808.

41 Ghoshal UC, Srivastava D: Irritable bowel syndrome and small intestinal bacterial overgrowth: meaningful association or unnecessary hype. World J Gastroenterol 2014;20: 2482-2491.

42 Stasi C, Rosselli M, Bellini M, Laffi G, Milani $S$ : Altered neuro-endocrine-immune pathways in the irritable bowel syndrome: the topdown and the bottom-up model. J Gastroenterol 2012;47:1177-1185.

43 Bonaz B: Inflammatory bowel diseases: a dysfunction of brain-gut interactions? Minerva Gastroenterol Dietol 2013;59:241-259.

44 Gershon MD: Nerves, reflexes, and the enteric nervous system: pathogenesis of the irritable bowel syndrome. I Clin Gastroenterol 2005;39:S184-S193.

45 Mayer EA, Berman S, Suyenobu B, Labus J, Mandelkern MA, Naliboff BD, Chang L: Differences in brain responses to visceral pain between patients with irritable bowel syndrome and ulcerative colitis. Pain 2005;115: 398-409.

46 Elsenbruch S, Rosenberger C, Bingel U, Forsting M, Schedlowski M, Gizewski ER: Patients with irritable bowel syndrome have altered emotional modulation of neural responses to visceral stimuli. Gastroenterology 2010;139: 1310-1319.

47 Eswaran S, Tack J, Chey WD: Food: the forgotten factor in the irritable bowel syndrome. Gastroenterol Clin North Am 2011;40:141-162.

48 Chirila I, Petrariu FD, Ciortescu I, Mihai C, Drug VL: Diet and irritable bowel syndrome. J Gastrointestin Liver Dis 2012;21:357-362.

49 Friedman G: Diet and the irritable bowel syndrome. Gastroenterol Clin North Am 1991; 20:313-324

50 Dapoigny M, Stockbrügger RW, Azpiroz F, Collins S, Coremans G, Müller-Lissner S, Oberndorff A, Pace F, Smout A, Vatn M, Whorwell P: Role of alimentation in irritable bowel syndrome. Digestion 2003;67:225-233.

51 El-Salhy M, Gundersen D: Diet in irritable bowel syndrome. Nutr J 2015;14:36.
52 Barbara G, Stanghellini V, De Giorgio R, Cremon C, Cottrell GS, Santini D, Pasquinelli G, Morselli-Labate AM, Grady EF, Bunnett NW, Collins SM, Corinaldesi R: Activated mast cells in proximity to colonic nerves correlate with abdominal pain in irritable bowel syndrome. Gastroenterology 2004;126:693-702.

53 Cremon C, Carini G, Wang B, Vasina V, Cogliandro RF, De Giorgio R, Stanghellini V, Grundy D, Tonini M, De Ponti F, Corinaldesi R, Barbara G: Intestinal serotonin release, sensory neuron activation, and abdominal pain in irritable bowel syndrome. Am J Gastroenterol 2011;106:1290-1298.

54 Philpott H, Gibson P, Thien F: Irritable bowel syndrome - an inflammatory disease involving mast cells. Asia Pac Allergy 2011;1:36-42.

55 Talley NJ, Dennis EH, Schettler-Duncan VA, Lacy BE, Olden KW, Crowell MD: Overlapping upper and lower gastrointestinal symptoms in irritable bowel syndrome patients with constipation or diarrhea. Am J Gastroenterol 2003;98:2454-2459.

56 Yu SW, Rao SS: Advances in the management of constipation-predominant irritable bowel syndrome: the role of linaclotide. Therap Adv Gastroenterol 2014;7:193-205.

57 Carter NJ, Scott LJ: Lubiprostone: in constipation-predominant irritable bowel syndrome. Drugs 2009;69:1229-1237.

58 Khoshoo V, Armstead C, Landry L: Effect of a laxative with and without tegaserod in adolescents with constipation predominant irritable bowel syndrome. Aliment Pharmacol Ther 2006;23:191-196.

59 Enck P, Junne F, Klosterhalfen S, Zipfel S, Martens U: Therapy options in irritable bowel syndrome. Eur J Gastroenterol Hepatol 2010;22:1402-1411.

60 Tougas G, Snape WJ Jr, Otten MH, Earnest DL, Langaker KE, Pruitt RE, Pecher E, Nault B, Rojavin MA: Long-term safety of tegaserod in patients with constipation-predominant irritable bowel syndrome. Aliment Pharmacol Ther 2002;16:1701-1708.

61 Tegaserod: withdrawal from the world market. A treatment for constipation with cardiovascular adverse effects. Prescrire Int 2008;17: $112-113$.

62 Camilleri M, Kerstens R, Rykx A, Vandeplassche L: A placebo-controlled trial of prucalopride for severe chronic constipation. N Engl J Med 2008;358:2344-2354.

63 Emmanuel A, Cools M, Vandeplassche L, Kerstens R: Prucalopride improves bowel function and colonic transit time in patients with chronic constipation: an integrated analysis. Am J Gastroenterol 2014;109:887-894.

64 Olden KW: Irritable bowel syndrome: an overview of diagnosis and pharmacologic treatment. Cleve Clin J Med 2003;70(suppl 2):S3-S7.

65 Mendzelevski B, Ausma J, Chanter DO, Robinson P, Kerstens R, Vandeplassche L, Camm $\mathrm{J}$ : Assessment of the cardiac safety of prucalopride in healthy volunteers: a randomized, double-blind, placebo- and positive-con- trolled thorough QT study. Br J Clin Pharmacol 2012;73:203-209.

66 Thayalasekeran S, Ali H, Tsai HH: Novel therapies for constipation. World J Gastroenterol 2013;19:8247-8251.

67 Evangelista S: Drug evaluation: pumosetrag for the treatment of irritable bowel syndrome and gastroesophageal reflux disease. Curr Opin Investig Drugs 2007;8:416-422.

68 Wang SH, Lin CY, Huang TY, Wu WS, Chen CC, Tsai SH: QT interval effects of cisapride in the clinical setting. Int J Cardiol 2001;80: 179-183.

69 Heading R, Bardhan K, Hollerbach S, Lanas A, Fisher G: Systematic review: the safety and tolerability of pharmacological agents for treatment of irritable bowel syndrome - a European perspective. Aliment Pharmacol Ther 2006;24:207-236.

70 Aboumarzouk OM, Agarwal T, Antakia R, Shariff U, Nelson RL: Cisapride for intestinal constipation. Cochrane Database Syst Rev 2011;1:CD007780.

71 Goldberg M, Li YP, Johanson JF, Mangel AW, Kitt M, Beattie DT, Kersey K, Daniels O Clinical trial: the efficacy and tolerability of velusetrag, a selective 5-HT4 agonist with high intrinsic activity, in chronic idiopathic constipation - a 4-week, randomized, double-blind, placebo-controlled, dose-response study. Aliment Pharmacol Ther 2010;32: 1102-1112.

72 Cann PA, Read NW, Holdsworth CD, Barends $D$ : Role of loperamide and placebo in management of irritable bowel syndrome (IBS). Dig Dis Sci 1984;29:239-247.

73 Jailwala J, Imperiale TF, Kroenke K: Pharmacologic treatment of the irritable bowel syndrome: a systematic review of randomized, controlled trials. Ann Intern Med 2000;133: 136-147.

74 Layer P, Andresen V, Pehl C, Allescher H, Bischoff SC, Classen M, Enck P, Frieling T, Haag S, Holtmann G, Karaus M, Kathemann S, Keller J, Kuhlbusch-Zicklam R, Kruis W, Langhorst J, Matthes H, Mönnikes H, MüllerLissner S, Musial F, Otto B, Rosenberger C, Schemann M, van der Voort I, Dathe K, Preiss JC: Irritable bowel syndrome: German consensus guidelines on definition, pathophysiology and management. Z Gastroenterol 2011;49:237-293

75 Camilleri M, Mayer EA, Drossman DA, Heath A, Dukes GE, McSorley D, Kong S, Mangel AW, Northcutt AR: Improvement in pain and bowel function in female irritable bowel patients with alosetron, a $5-\mathrm{HT}_{3}$ receptor antagonist. Aliment Pharmacol Ther 1999;13:1149-1159.

76 Crutchley RD, Miller J, Garey KW: Crofelemer, a novel agent for treatment ofsecretory diarrhea. Ann Pharmacother 2010;44:878884

77 Mangel AW, Chaturvedi P: Evaluation of crofelemer in the treatment of diarrhea-predominant irritable bowel syndrome patients. Digestion 2008;78:180-186. 
78 Malcolm A, Camilleri M, Kost L, Burton DD, Fett SL, Zinsmeister AR: Towards identifying optimal doses for alpha-2 adrenergic modulation of colonic and rectal motor and sensory function. Aliment Pharmacol Ther 2000;14: 783-793.

79 Bharucha AE, Fletcher JG, Camilleri M, Edge J, Carlson P, Zinsmeister AR: Effects of clonidine in women with fecal incontinence. Clin Gastroenterol Hepatol 2014;12:843851.e2.

80 Grudell $A B$, Camilleri M, Jensen KL, FoxxOrenstein AE, Burton DD, Ryks MD, Baxter KL, Cox DS, Dukes GE, Kelleher DL, Zinsmeister AR: Dose-response effect of a beta3adrenergic receptor agonist, solabegron, on gastrointestinal transit, bowel function, and somatostatin levels in health. Am J Physiol Gastrointest Liver Physiol 2008;294:G1114G1119.

81 Schemann M, Hafsi N, Michel K, Kober OI, Wollmann J, Li Q, Zeller F, Langer R, Lee K, Cellek S: The beta3-adrenoceptor agonist GW427353 (Solabegron) decreases excitability of human enteric neurons via release of somatostatin. Gastroenterology 2010;138:266274.

82 Bradette M, Delvaux M, Staumont G, Fioramonti J, Bueno L, Frexinos J: Octreotide increases thresholds of colonic visceral perception in IBS patients without modifying muscle tone. Dig Dis Sci 1994;39:1171-1178.

83 Klooker TK, Kuiken SD, Lei A, Boeckxstaens GE: Effect of long-term treatment with octreotide on rectal sensitivity in patients with non-constipated irritable bowel syndrome. Aliment Pharmacol Ther 2007;26: 605-615.

84 Ford AC, Talley NJ, Schoenfeld PS, Quigley EM, Moayyedi P: Efficacy of antidepressants and psychological therapies in irritable bowel syndrome: systematic review and meta-analysis. Gut 2009;58:367-378.

85 Andresen V, Keller J, Pehl C, Schemann M, Preiss J, Layer P: Irritable bowel syndrome the main recommendations. Dtsch Arztebl Int 2011;108:751-760.

86 Sinagra E, Romano C, Cottone M: Psychopharmacological treatment and psychological interventions in irritable bowel syndrome. Gastroenterol Res Pract 2012;2012: 486067.

87 Morgan V, Pickens D, Gautam S, Kessler R, Mertz H: Amitriptyline reduces rectal pain related activation of the anterior cingulate cortex in patients with irritable bowel syndrome. Gut 2005;54:601-607.

88 Vahedi H, Merat S, Rashidioon A, Ghoddoosi A, Malekzadeh R: The effect of fluoxetine in patients with pain and constipation-predominant irritable bowel syndrome: a doubleblind randomized-controlled study. Aliment Pharmacol Ther 2005;22:381-385.

89 Salari P, Abdollahi M: Systematic review of modulators of benzodiazepine receptors in irritable bowel syndrome: is there hope? World J Gastroenterol 2011;17:4251-4257.
90 Houghton LA, Fell C, Whorwell PJ, Jones I, Sudworth DP, Gale JD: Effect of a secondgeneration alpha2delta ligand (pregabalin) on visceral sensation in hypersensitive patients with irritable bowel syndrome. Gut 2007;56:1218-1225.

91 Song GH, Leng PH, Gwee KA, Moochhala SM, Ho KY: Melatonin improves abdominal pain in irritable bowel syndrome patients who have sleep disturbances: a randomised, double blind, placebo controlled study. Gut 2005;54:1402-1407.

92 Ladabaum U, Sharabidze A, Levin TR, Zhao WK, Chung E, Bacchetti P, Jin C, Grimes B, Pepin CJ: Citalopram provides little or no benefit in nondepressed patients with irritable bowel syndrome. Clin Gastroenterol Hepatol 2010;8:42-48.e1.

93 Ford AC, Talley NJ, Spiegel BM, Foxx-Orenstein AE, Schiller L, Quigley EM, Moayyedi P: Effect of fibre, antispasmodics, and peppermint oil in the treatment of irritable bowel syndrome: systematic review and metaanalysis. BMJ 2008;337:a2313.

94 Darvish-Damavandi M, Nikfar S, Abdollahi M: A systematic review of efficacy and tolerability of mebeverine in irritable bowel syndrome. World J Gastroenterol 2010;16:547553.

95 McKenzie YA, Alder A, Anderson W, Wills A, Goddard L, Gulia P, Jankovich E, Mutch P, Reeves LB, Singer A, Lomer MC; Gastroenterology Specialist Group of the British Dietetic Association: British dietetic asssociation evidence-based guidelines for the dietary management of irritable bowel syndrome in adults. J Hum Nutr Diet 2012;25: 260-274.

96 Saxelin M, Tynkkynen S, Mattila-Sandholm T, de Vos WM: Probiotic and other functional microbes: from markets to mechanisms. Curr Opin Biotechnol 2005;16:204-211.

97 Spiller R: Review article: probiotics and prebiotics in irritable bowel syndrome. Aliment Pharmacol Ther 2008;28:385-396.

98 Whorwell PJ, Altringer L, Morel J, Bond Y, Charbonneau D, O'Mahony L, Kiely B, Shanahan F, Quigley EM: Efficacy of an encapsulated probiotic Bifidobacterium infantis 35,624 in women with irritable bowel syndrome. Am J Gastroenterol 2006;101:15811590.

99 Sinn DH, Song JH, Kim HJ, Lee JH, Son HJ, Chang DK, Kim YH, Kim JJ, Rhee JC, Rhee PL: Therapeutic effect of Lactobacillus acidophilus-SDC 2012, 2013 in patients with irritable bowel syndrome. Dig Dis Sci 2008;53: 2714-2718.

100 Begtrup LM, de Muckadell OB, Kjeldsen J, Christensen RD, Jarbøl DE: Long-term treatment with probiotics in primary care patients with irritable bowel syndrome - a randomised, double-blind, placebo controlled trial. Scand J Gastroenterol 2013;48: 1127-1135.

101 Basseri RJ, Weitsman S, Barlow GM, Pimentel M: Antibiotics for the treatment of irri- table bowel syndrome. Gastroenterol Hepatol (N Y) 2011;7:455-493.

102 Pimentel M, Lembo A, Chey WD, Zakko S Ringel Y, Yu J, Mareya SM, Shaw AL, Bortey E, Forbes WP; TARGET Study Group: Rifaximin therapy for patients with irritable bowel syndrome without constipation. N Engl J Med 2011;364:22-32.

103 Nayak AK, Karnad DR, Abraham P, Mistry FP: Metronidazole relieves symptoms in irritable bowel syndrome: the confusion with so-called 'chronic amebiasis'. Indian J Gastroenterol 1997;16:137-139.

104 Pimentel M, Chatterjee S, Chow EJ, Park S, Kong Y: Neomycin improves constipationpredominant irritable bowel syndrome in a fashion that is dependent on the presence of methane gas: subanalysis of a double-blind randomized controlled study. Dig Dis Sci 2006;51:1297-1301.

105 Rezaie A, Nikfar S, Abdollahi M: The place of antibiotics in management of irritable bowel syndrome: a systematic review and meta-analysis. Arch Med Sci 2010;6:49-55.

106 Bolin TD: Use of oral sodium cromoglycate in persistent diarrhoea. Gut 1980;21:848-850.

107 Klooker TK, Braak B, Koopman KE, Welting $\mathrm{O}$, Wouters MM, van der Heide S, Schemann M, Bischoff SC, van den Wijngaard RM, Boeckxstaens GE: The mast cell stabiliser ketotifen decreases visceral hypersensitivity and improves intestinal symptoms in patients with irritable bowel syndrome. Gut 2010;59:1213-1221.

108 Andrews CN, Griffiths TA, Kaufman J, Vergnolle N, Surette MG, Rioux KP: Mesalazine (5-aminosalicylic acid) alters faecal bacterial profiles, but not mucosal proteolytic activity in diarrhoea-predominant irritable bowel syndrome. Aliment Pharmacol Ther 2011;34:374-383.

109 Lam C, Tan W, Leighton M, Hastings M, Lingaya $\mathrm{M}$, Falcone $\mathrm{Y}$, Zhou $\mathrm{X}$, Xu L, Whorwell $\mathrm{P}$, Walls AF, Zaitoun A, Montgomery A, Spiller R: A mechanistic multicentre, parallel group, randomised placebo-controlled trial of mesalazine for the treatment of IBS with diarrhoea (IBS-D). Gut 2015, Epub ahead of print.

110 Schicho R, Storr M: Alternative targets within the endocannabinoid system for future treatment of gastrointestinal diseases. Can J Gastroenterol 2011;25:377-383.

111 Wilner LS, Arnold RM: Cannabinoids in the treatment of symptoms in cancer and AIDS \#93. J Palliat Med 2006;9:802-804.

112 Boesmans W, Ameloot K, van den Abbeel V, Tack J, Vanden Berghe P: Cannabinoid receptor 1 signalling dampens activity and mitochondrial transport in networks of enteric neurones. Neurogastroenterol Motil 2009; 21:e958-e977.

113 Izzo AA, Fezza F, Capasso R, Bisogno T, Pinto L, Iuvone T, Esposito G, Mascolo N, Di Marzo V, Capasso F: Cannabinoid CB1-receptor mediated regulation of gastrointestinal motility in mice in a model of intestinal inflammation. Br J Pharmacol 2001;134:563-570. 
114 Naftali T, Bar-Lev Schleider L, Dotan I, Lansky EP, Sklerovsky Benjaminov F, Konikoff FM: Cannabis induces a clinical response in patients with Crohn's disease: a prospective placebo-controlled study. Clin Gastroenterol Hepatol 2013;11:1276-1280.e1.

115 Goodwin RS, Gustafson RA, Barnes A, Nebro W, Moolchan ET, Huestis MA: Delta (9)-tetrahydrocannabinol, 11-hydroxy-delta(9)-tetrahydrocannabinol and 11-nor9-carboxy-delta(9)-tetrahydrocannabinol in human plasma after controlled oral administration of cannabinoids. Ther Drug Monit 2006;28:545-551.

116 Wong BS, Camilleri M, Busciglio I, Carlson P, Szarka LA, Burton D, Zinsmeister AR: Pharmacogenetic trial of a cannabinoid agonist shows reduced fasting colonic motility in patients with nonconstipated irritable bowel syndrome. Gastroenterology 2011; 141:1638-1647.e1-e7.
117 Wong BS, Camilleri M, Eckert D, Carlson P, Ryks M, Burton D, Zinsmeister AR: Randomized pharmacodynamic and pharmacogenetic trial of dronabinol effects on colon transit in irritable bowel syndrome-diarrhea. Neurogastroenterol Motil 2012;24: 358.e169.

118 Rahimi R, Abdollahi M: Herbal medicines for the management of irritable bowel syndrome: a comprehensive review. World J Gastroenterol 2012;18:589-600.

119 Tang ZP: Traditional Chinese medicine clinical experience of the treatment for irritable bowel syndrome. Chin J Integr Med 2009;15:93-94.

120 Chedid V, Dhalla S, Clarke JO, Roland BC, Dunbar KB, Koh J, Justino E, Tomakin E, Mullin GE: Herbal therapy is equivalent to rifaximin for the treatment of small intestinal bacterial overgrowth. Glob Adv Health Med 2014;3:16-24.
$121 \mathrm{Wu}$ J, Luo S: Jian shu wen qing tang used in the treatment for 60 cases of irritable bowel syndrome. J Tradit Chin Med 2004;24:100-101.

122 Manheimer E, Cheng K, Wieland LS, Min LS, Shen X, Berman BM, Lao L: Acupuncture for treatment of irritable bowel syndrome. Cochrane Database Syst Rev 2012; 5:CD005111.

123 Lim B, Manheimer E, Lao L, Ziea E, Wisniewski J, Liu J, Berman B: Acupuncture for treatment of irritable bowel syndrome. Cochrane Database Syst Rev 2006;4:CD005111.

124 Gonsalkorale WM, Toner BB, Whorwell PJ: Cognitive change in patients undergoing hypnotherapy for irritable bowel syndrome. J Psychosom Res 2004;56:271-278.

125 Pinn DM, Aroniadis OC, Brandt LJ: Is fecal microbiota transplantation (FMT) an effective treatment for patients with functional gastrointestinal disorders (FGID)? Neurogastroenterol Motil 2015;27:19-29. 